\title{
Do microplates in subduction zones leave a geological record?
}

\author{
Joann M. Stock and Jeffrey Lee ${ }^{1}$ \\ Seismological Laboratory, California Institute of Technology, Pasadena
}

Abstract. Active microplate boundaries in ocean-continent subduction zones may induce deformation of the overlying plate and spatial or geochemical variations in the volcanic arc. We discuss two modern cases. The first is the South Gorda-Juan de Fuca plate boundary in the Cascadia subduction zone, where there is little or no effect on the overriding plate and the oceanic plate takes up much of the deformation. The second case is the Cocos-Rivera plate boundary in the Middle America trench, where the overlying Colima graben contains substantial deformation in a zone extending from the trench to the volcanic arc and the subduction-related volcanism is spatially and geochemically complex. We apply these observations to boundaries of the Arguello, Monterey, Guadalupe, and Magdalena microplates, which existed in the subduction zone west of Baja California at various times from 20 to $12.5 \mathrm{Ma}$. The past positions of these boundaries relative to Baja California are constrained by global plate reconstructions, closure of the Gulf of California, and an estimate of extension in the Mexican Basin and Range province. Existing regional mapping and our additional reconnaissance mapping show that Paleocene to Eocene fluvial and marine sedimentary rocks south of Ensenada along the western Baja California peninsula and eastward to the mid-Miocene volcanic arc are undeformed. Limited available data reveal no major spatial or geochemical variations in the mid-Miocene volcanic arc that might correlate with the past positions of the microplate boundaries. Thus these microplate boundaries had little to no effect on the overriding continental plate. The nature of Guadalupe and Magdalena interactions with North America may have been closer to the South Gorda-Juan de Fuca example, with possible internal deformation of the microplates. The Monterey and Arguello microplates may have behaved like the modern Explorer plate, with largely strike-slip motion relative to North America during their last stages of existence. Tectonic patterns similar to these examples may be expected from other plate boundaries where a plate is fragmenting as it enters a subduction zone (e.g., the Aluk plate in the trench beneath West Antarctica in early Tertiary time). Whether these microplates subsequently become attached to the overriding continental plate or to a larger oceanic plate and whether this causes deformation in the region of the former subduction zone may depend on the velocities of the nearby major plates and the relative orientations of the microplate boundaries.

${ }^{1}$ Now at Geology Department, Central Washington University, Ellensburg.

Copyright 1994 by the American Geophysical Union.

Paper number 94TC01808.

0278-7407/94/94TC01808\$10.00

\section{Introduction}

As a spreading center approaches a trench in a subduction setting, the intervening subducted plate may fragment into smaller pieces down to linear dimensions of $-100 \mathrm{~km}$ (microplates). A recent example of this process is provided by the Farallon plate, which broke into progressively smaller pieces as the Pacific-Farallon ridge approached the subduction zone west of North America [Atwater, 1970; Menard, 1978; Lonsdale, 1991], following the history illustrated in Figure 1. Some of the small plates that resulted from a recent period of fragmentation are the Explorer plate and the South Gorda plate. These started moving independently at $\sim 5$ and $\sim 3 \mathrm{Ma}$ at the northernmost and southernmost edges of the Juan de Fuca plate along the Cascadia subduction zone (Figure 2). Another small plate, the Rivera plate, recently $(-5 \mathrm{Ma})$ separated from the much larger Cocos plate at the northern end of the Middle America trench (Figure 3). Examples of similar plate fragmentation of Miocene age lie in the marine geology offshore California and Baja California [Lonsdale, 1991; Atwater, 1989] (Figures 4a-4d).

The fragmentation of a subducting plate creates a new triple junction, two limbs of which are along the trench. If the two subducting plate fragments then diverge rapidly enough, a spreading center may form between them, so that the newly formed triple junction quickly evolves to a trench-trench-ridge (TTR) geometry. (For example, the fragmentation of the Farallon plate into Cocos and Nazca plates created a new spreading center, the Galapagos Rise, between Nazca and Cocos.) If the two plate fragments converge rapidly, then, presumably, intraoceanic subduction might result, although we know of no well-documented examples of this in the geological record. However, if the relative motion between the two downgoing plate fragments is slow, as in the modern examples discussed here, then a more complex deformation pattern is observed between the two subducting plates. As discussed below, the relative motion may be taken up within a wide zone of internal deformation and seismicity of the downgoing plates themselves (e.g., the South Gorda deformation zone within the Juan de Fuca plate) or by formation of localized grabens and transtensional structures within the downgoing plate (e.g., Rivera-Cocos boundary). Triple junctions must still be present between the plates, but they may not be as simple as those usually envisioned. For example, the modern Cocos-Rivera-North America triple junction at the Middle America Trench has two limbs that are trenches and one limb that is an oblique extensional zone between the Cocos and Rivera plates. Kinematically, this configuration is equivalent to a TTR triple junction but, in practice, is quite different since there is diffuse oblique extension, not seafloor spreading.

The response to plate fragmentation may also depend on 


\section{GENEALOGY OF THE FARALLON PLATE}

(modified from Lonsdale, 1991)

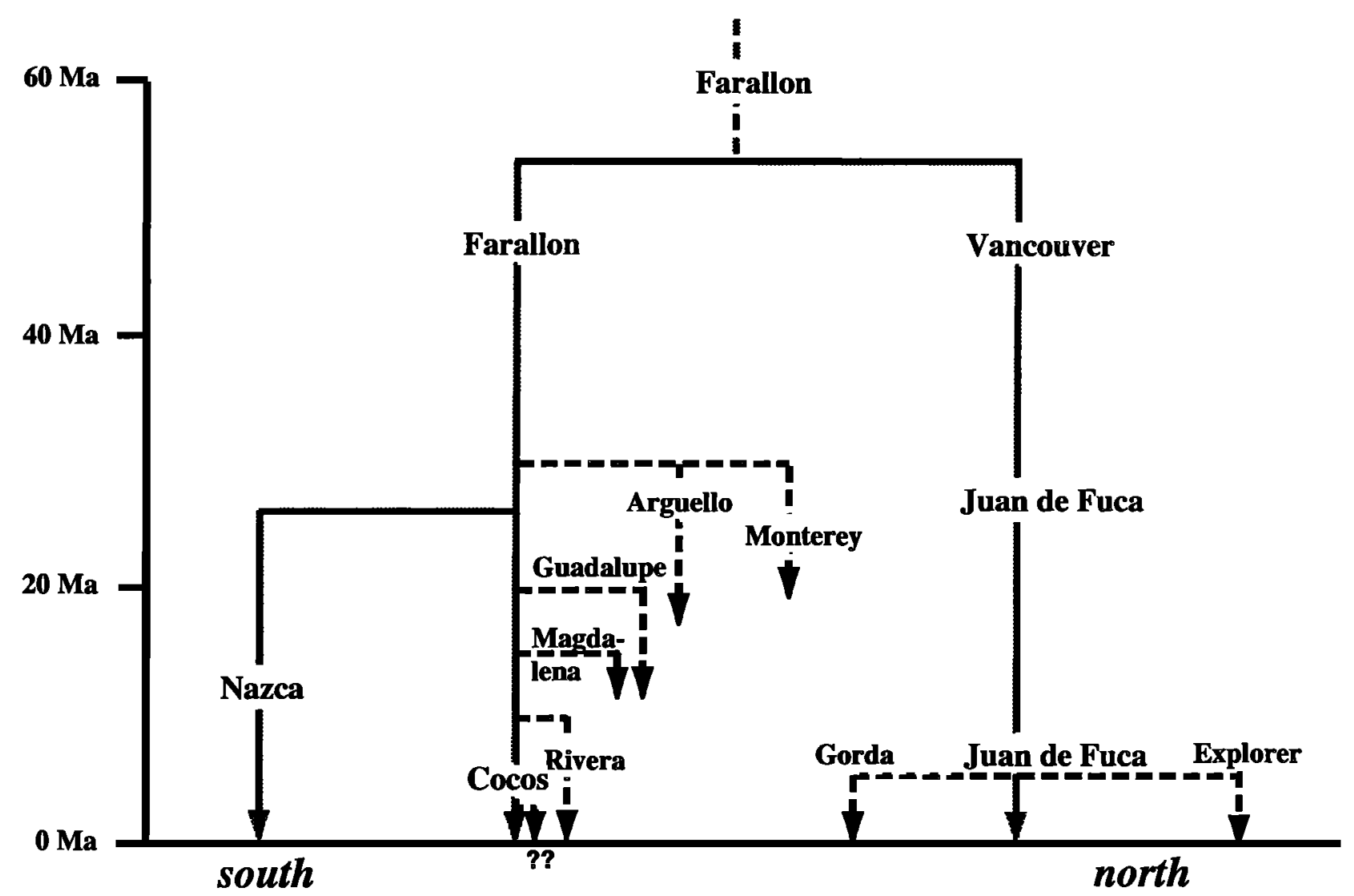

Figure 1. Time line showing the genealogy of breakup of the Farallon plate into smaller fragments, following the detailed microplate histories of Atwater [1989] and Lonsdale [1991].

the size of the resulting plates. A large plate may be driven by slab-pull and ridge-push stresses which may not change much if the plate is broken into two, equal size pieces. However, if a small fragment breaks off a large plate, then it may lose its slab-pull force and become driven entirely by different conditions. In addition, small plate fragments are generally broken off larger plates in the region near the spreading ridge. Thus the average age of smaller plate fragments is generally much younger than the average age of larger plates, such that smaller plates are thinner, weaker, and more easily deformed. As a result, smaller plates experience less slab-pull force, such that their motions may be able to change quite rapidly.

Small sizes and slow rates of relative motion are characteristic of the fragments of the former Farallon plate that were subducted beneath western North America in late Tertiary time. In many cases the boundaries between these plates, where they entered the subduction zone, were probably not spreading ridges but, rather, transform faults, zones of diffuse extension, or perhaps distributed shear. Here we evaluate kinematics and expected processes while these microplates were still moving relative to the major plates. We discuss the two following examples from the present-day western margin of the North America plate that may be viewed as end-member cases: (1) tectonic settings where the presence of microplate boundaries in the subduction zone has little to no effect on the geology of the overriding plate and (2) tectonic settings where substantial fragmentation of the overriding plate results. We then apply these observations to interpret the kinematics of past microplate boundaries along the western margin of Baja California. We do not discuss processes that occur after microplate death, although these affect the later geological development of the region near the subduction zone [e.g., Nicholson et al., 1994; R. G. Bohannon and T. Parsons, Tectonic implications of post-30 Ma Pacific and North American plate motions, submitted to Geological Society of America,Bulletin, 1994].

\section{Present-Day Subduction: North America \\ Cascadia Subduction Zone: Little to No \\ Continental Deformation Correlating With Microplate Boundarles}

At the Cascadia subduction zone the Juan de Fuca plate, the Explorer plate, and the "Gorda deformation zone" [Wilson, 1989] or South Gorda plate [Riddihough, 1984] are caught between the larger North America and Pacific plates. 


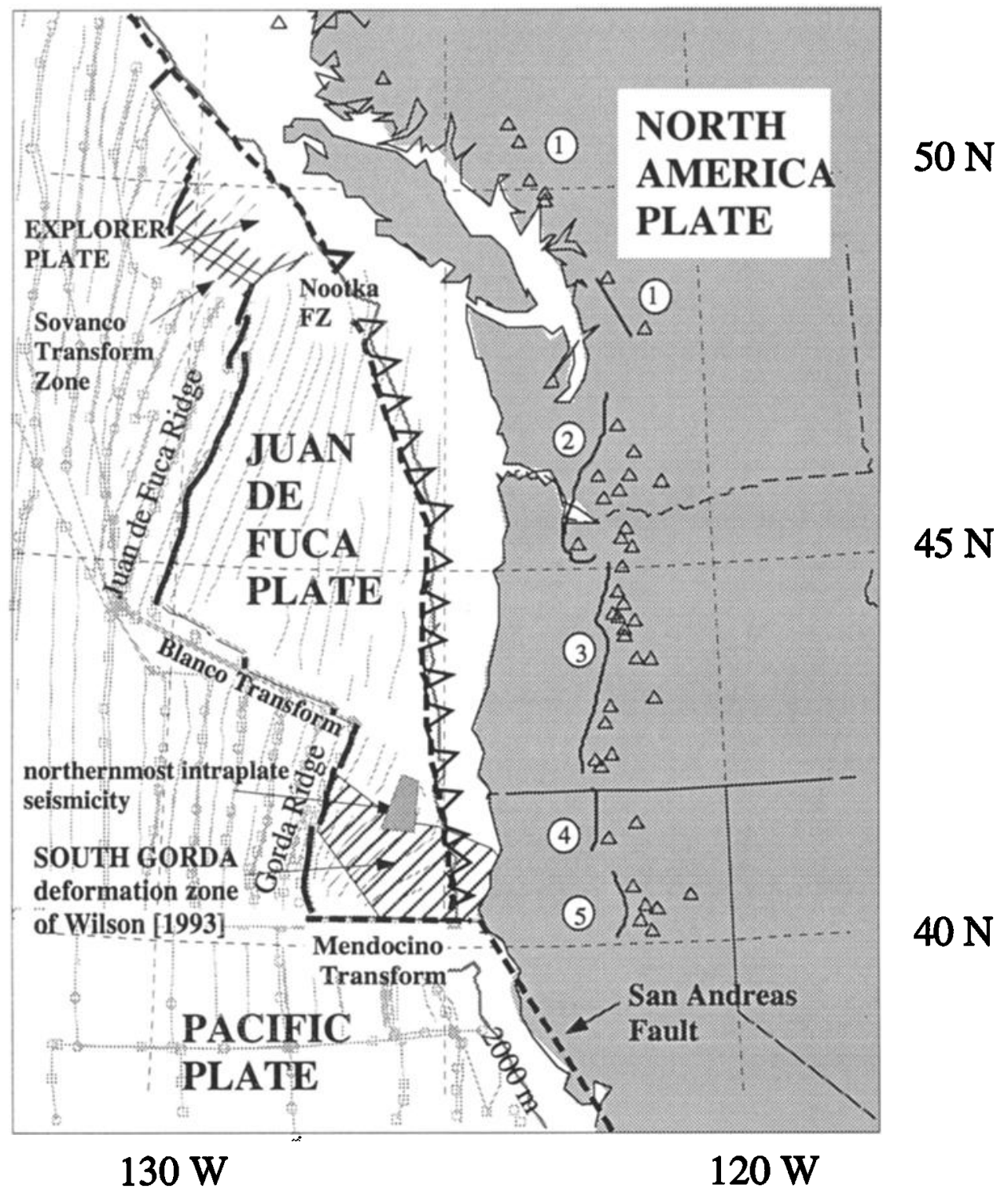

Figure 2. Present plate and microplate configuration along the Cascadia subduction zone showing Juan de Fuca plate and related microplates (Explorer and South Gorda). Thick lines indicate spreading ridges; thin lines are transform faults. Microplate geometry is from Riddihough [1984], Wilson [1993], and other references in text. Ridge geometry is from Atwater and Severinghaus [1989]. Young volcanic centers in the Cascades, shown as triangles, are from Wood and Kienle [1990]. Segmentation of the active Cascades volcanic arc, shown by lines indicating the position of the volcanic front (where defined) and corresponding segment numbers in circles, is from Guffanti and Weaver [1988]. Diagonal shading in oceanic plates shows broad zones of deformation according to Wilson [1993]; dotted shading north of the South Gorda deformation zone indicates the northernmost, well-located, intraplate mainshock-aftershock sequence in this region [Smith et al., 1993].

The Juan de Fuca and Gorda plates are being subducted under North America; the Explorer plate is being translated NW parallel to the margin (Figure 2). The boundaries between the Explorer and Juan de Fuca plates and between the Juan de Fuca and South Gorda regions are zones of diffuse deformation. Juan de Fuca, Explorer, and South Gorda are all spreading away from the Pacific, but the magnetic anomaly record from Pacific-Explorer motion is quite recent and is not interpreted in detail [Rohr et al., 1993]. The Gorda ridge, located between the Juan de Fuca/South Gorda plate and the Pacific plate, and its well-developed magnetic anomalies, change in strike from north to south (Figure 2). These changes are of interest because if there were no data from east of the spreading center, one might attribute the change in strike of the Gorda Ridge and of west (Pacific) side magnetic anomalies $2 \mathrm{~A}$ and younger ( $3 \mathrm{Ma}$ to present) 


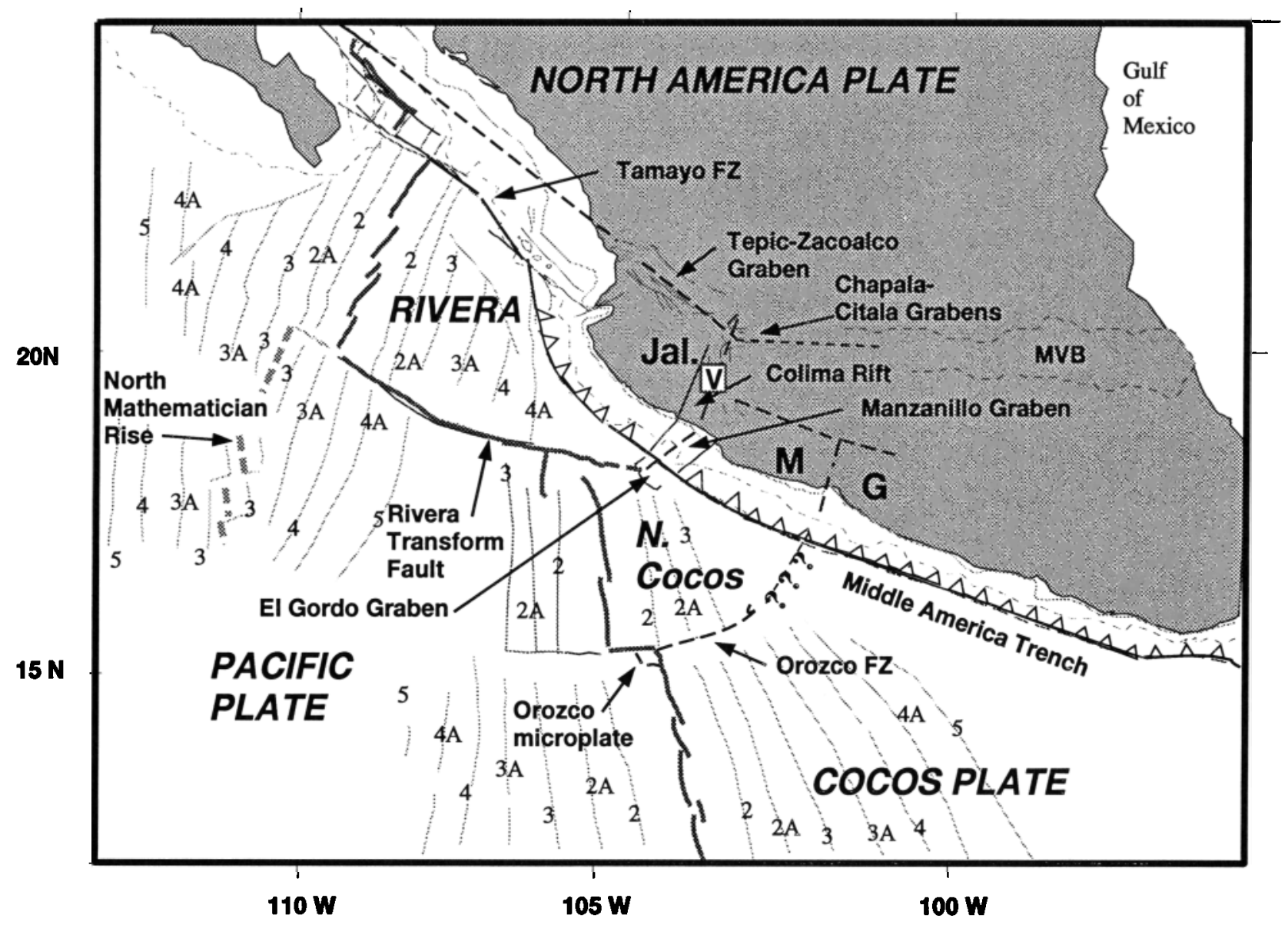

Figure 3. Current plate configuration in western Mexico and major belts of onshore deformation and volcanism. Major plates are Pacific, Cocos, Rivera, and North America. MVB is Mexican Volcanic Belt; FZ, fracture zone. Continental blocks that may be moving independently relative to the North America plate include Jalisco (Jal.), Michoacán (M), and Guerrero (G). Also shown are 2000-m and 500$\mathrm{m}$ bathymetric contours. Magnetic anomalies are centers of normal polarity stripes [Atwater and Severinghaus, 1989] and have the following ages [Cande and Kent, 1992]: 2, 1.87 Ma; 2A, 3.08 Ma: 3, 4.54 Ma; 3A, 6.04 Ma; 4, 8.70 Ma; 4A, 9.28 Ma; and 5, 10.21 Ma. "V" in the open square is Volcán Colima.

to the existence of two different plates east of the ridge. However, the magnetic anomalies on the eastern side show that two distinct plates are not present in this region.

The Juan de Fuca plate appears to be somewhat coupled to the overriding plate in northern Oregon, as indicated by folds and faults that cross the trench, affecting both the oceanic plate and the continental shelf of the overriding (North America) plate [Goldfinger et al., 1992]. Farther south, adjacent to southern Oregon and northern California, a 200- x 200-km area of the oceanic plate east of the Gorda ridge and adjacent to the Mendocino transform fault is experiencing internal deformation, as indicated by diffuse seismicity and major, active strike-slip faults [Silver, 1971; Wilson, 1989; Smith et al., 1993] and by distortion of the seafloor magnetic anomaly patterns within much of the region [Wilson, 1986, 1993] (Figure 2). This region has been labeled the "South Gorda plate" [Riddihough, 1980] or the "Gorda deformation zone" [Wilson, 1989] and comprises the southern half of a "Gorda plate" that may have moved independently relative to the more northern Juan de Fuca plate between -3 and $-5 \mathrm{Ma}$ [Wilson, 1993].

The boundary between the south Gorda plate and the Juan de Fuca plate, located at the change in strike of the spreading ridge and magnetic anomalies, is not a discrete structure. In addition, young faulting and diffuse seismicity continues northward into a region where the magnetic anomalies are not visibly deformed [Smith et al., 1993]. This raises doubt whether the South Gorda plate should be considered an independent microplate or, rather, an internally deforming section of the Juan de Fuca plate [Wilson, 1989, 1993]. A knowledge of the slab configuration ("one plate or two?") in the subduction zone would resolve this problem. Unfortunately, there is little recorded seismicity from the Wadati-Benioff zone, such that it is not known whether the Wadati-Benioff zone is warped, planar, or broken into separate Gorda and Juan de Fuca slabs.

We note that the Mendocino Triple Junction and the internal features of the subduction zone (such as the trace of 


\section{ANOMALY 6 (old edge), 20.4 MA}

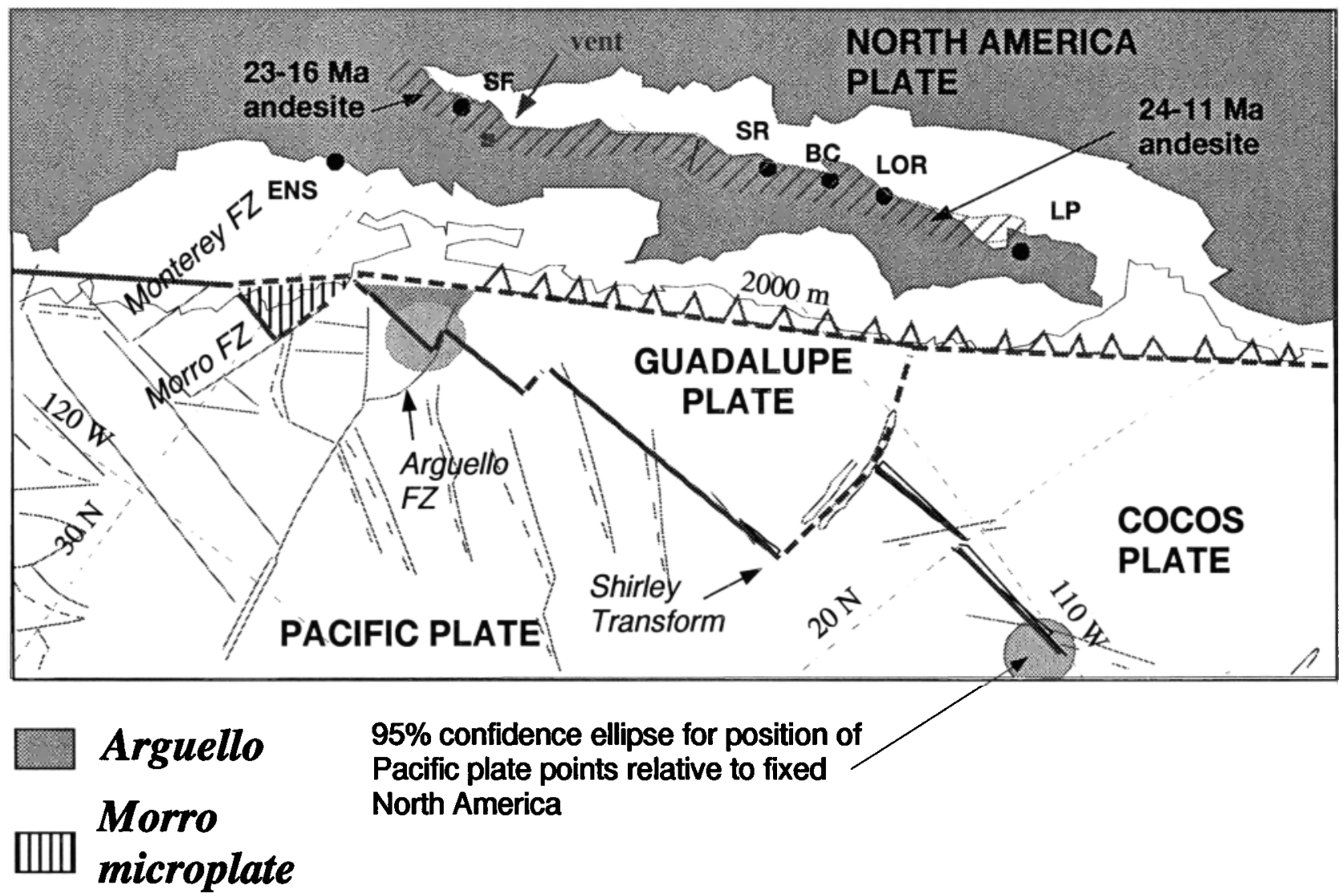

Figure 4a. Configuration of microplates west of Baja California at $20.4 \mathrm{Ma}$, based on global plate reconstructions of the Pacific plate to the North America plate [Stock and Molnar, 1988]. Time of magnetic anomalies ( 6 in Figure 4a) is given according to the Decade of North American Geology (DNAG) timescale; on the timescale of Cande and Kent [1992] this is the old edge of anomaly 6, 20.2 Ma. Marine magnetic anomalies indicating microplate configurations are from Lonsdale [1991] and Atwater and Severinghaus [1989]. Pseudo fault traces, shown as oblique solid lines with dashed counterparts, are from Atwater and Severinghaus [1989]. Locality abbreviations are SF, San Felipe; ENS, Ensenada; SR, Santa Rosalía; BC, Bahía Concepción; LOR, Loreto; and LP, La Paz. The 23-16 Ma and 24-11 Ma andesite belts are after Sawlan [1991]; vents south of San Felipe are from Martin-Barajas and Stock [1993] and Stock [1989]. Note that transform faults active at the time of a given reconstruction are labeled "transform," even though they are now fracture zones since they are no longer active. In addition to the reconstructions of rigid Pacific plate to a fixed North America plate, an additional 130 km of ENE directed extension has been removed from the Mexican Basin and Range Province. Rotations used are as follows: closure of Gulf of California, $48.6^{\circ} \mathrm{N},-75.15^{\circ} \mathrm{W}, 4.69^{\circ}$; and closure of Mexican Basin and Range, $52^{\circ} \mathrm{N}, 130^{\circ} \mathrm{E}, 1.2^{\circ}$.

the South Gorda-Juan de Fuca deformation zone) have had a component of trench-parallel motion of $\sim 48 \mathrm{~mm} / \mathrm{yr}$ northward relative to the North America plate (e.g., NUVEL 1 model of DeMets et al. [1990]). Thus the "microplate boundary" (if it is considered as such) has a component of motion parallel to the trench, so that it does not influence the geology at any position of the upper plate for any great length of time.

It appears that the present Gorda deformation zone and the earlier Juan de Fuca-Gorda plate boundary postulated by Wilson [1993] have had little to no recognizable manifesta- tion in the geology of the overlying North America plate. Although there is a zone of internal deformation in the subducted oceanic plate, there is no correlative structure in the overlying plate, such as a graben or other obvious transverse structure reaching from the trench into the active volcanic arc. Certainly, in this region there is nothing analogous to the present Colima Rift as described below. There may be a more subtle signal in the volcanic arc, however. The active Cascades arc is divisible into five major segments [Guffanti and Weaver, 1988] on the basis of geochemistry and location of vents $<5 \mathrm{Ma}$ in age (Figure 2). 


\section{ANOMALY 5D, 17.7 MA}

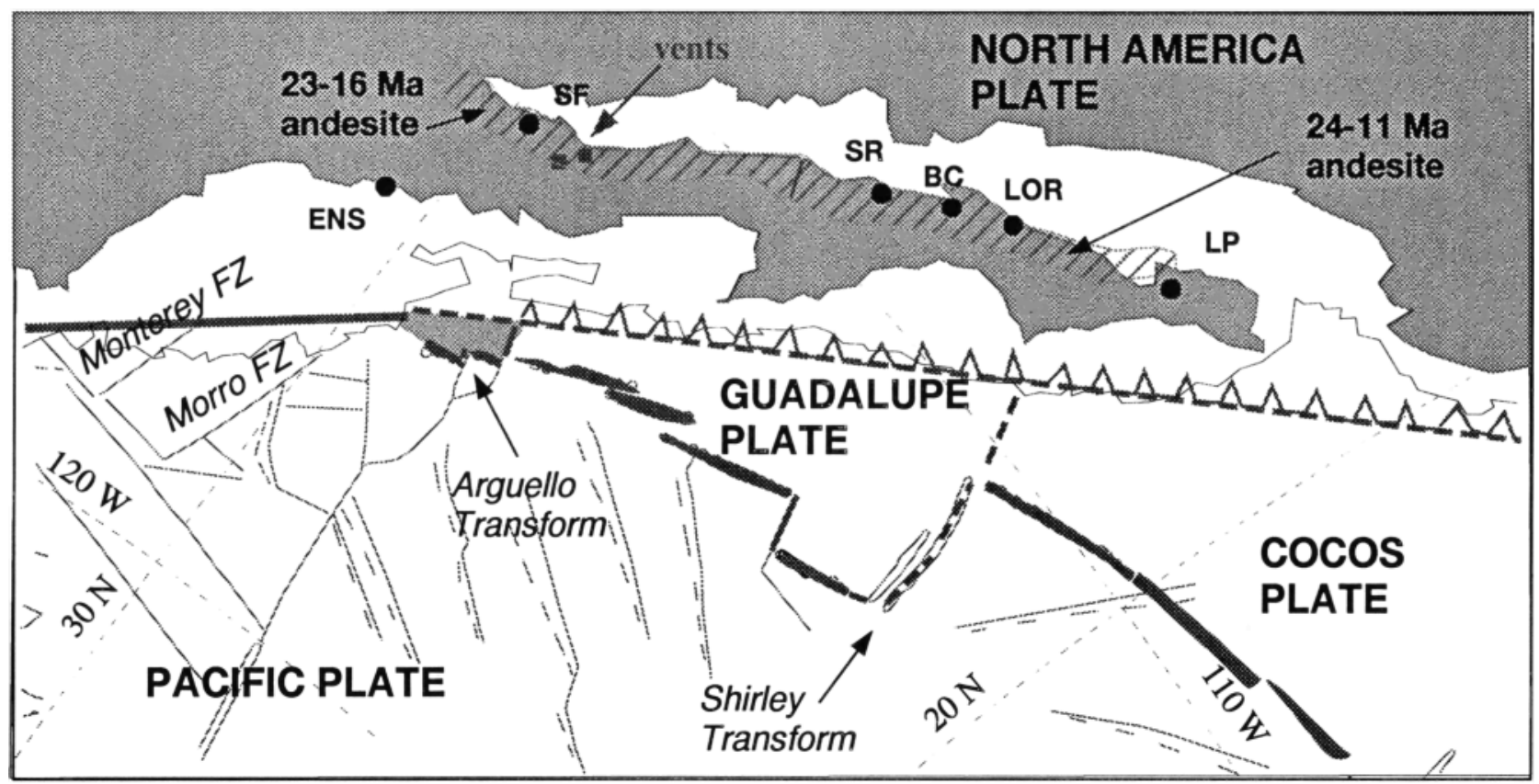

Arguello

\section{microplate}

Figure 4b. Same as Figure 4a, except for magnetic anomaly 5d, on DNAG timescale, 17.5 Ma.

\section{ANOMALY 5C, 16.2 MA}

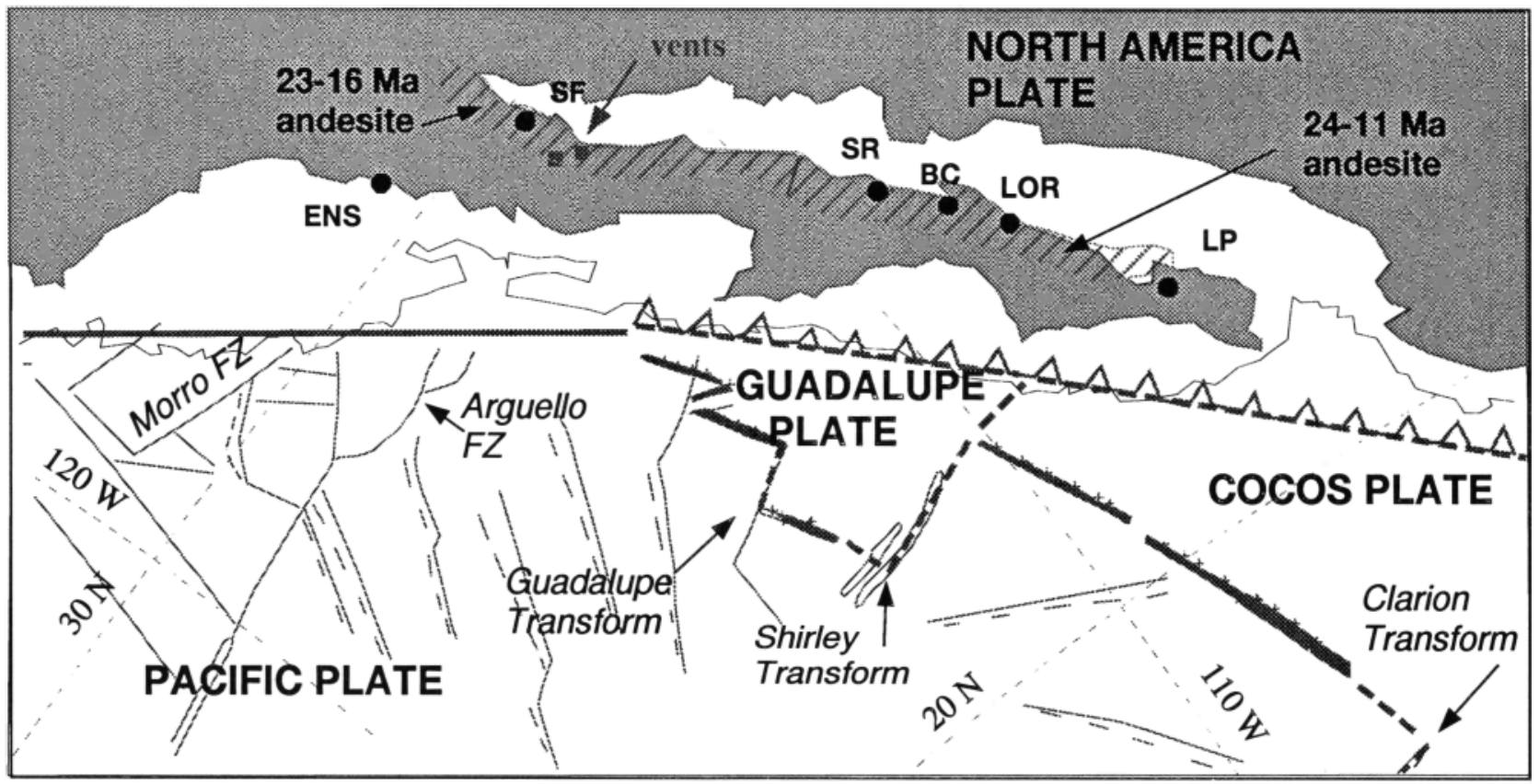

Figure 4c. Same as Figure 4a, except for magnetic anomaly 5c, $16.2 \mathrm{Ma}$. 
ANOMALY 5AA, 12.92 MA

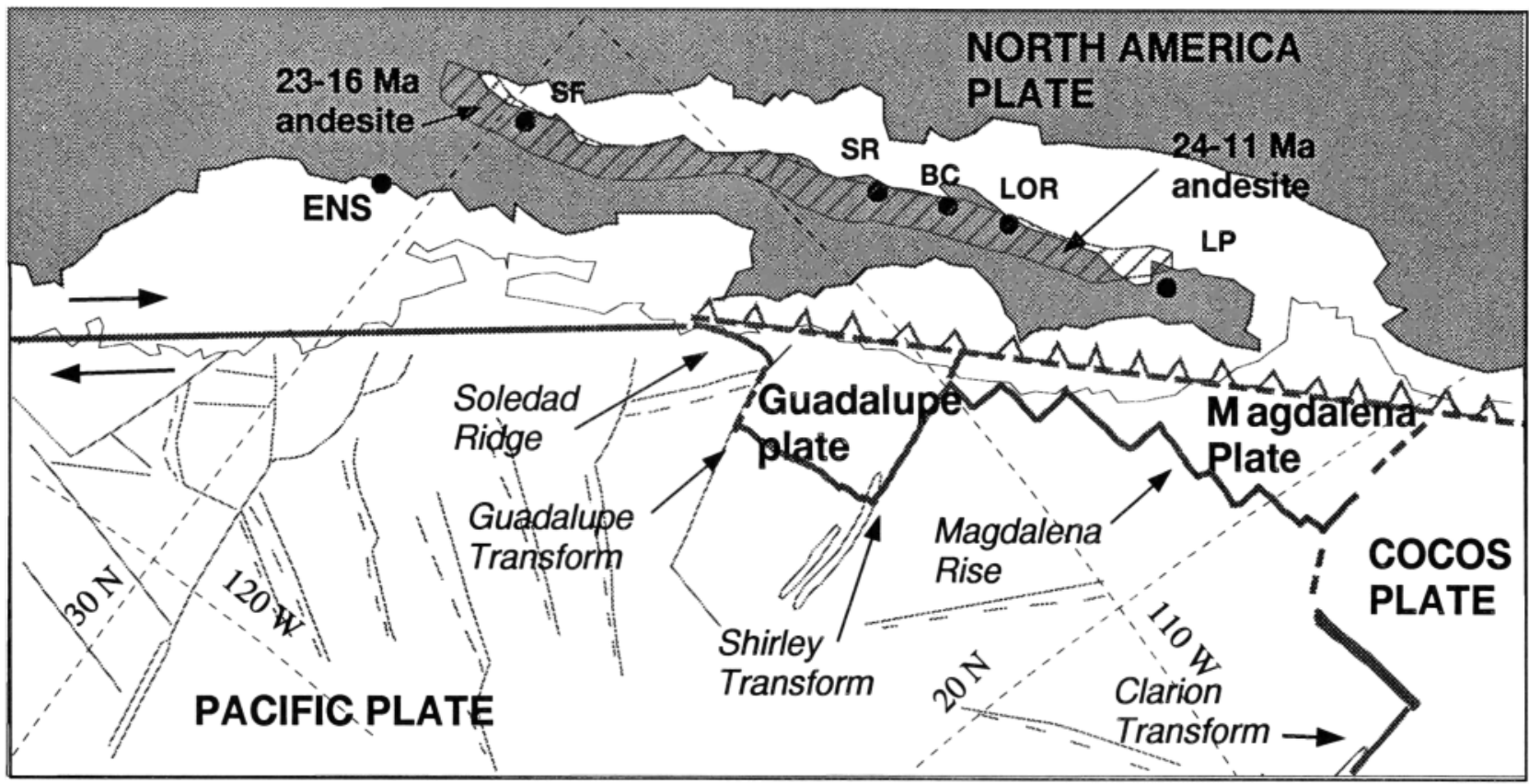

Figure 4d. Same as Figure 4a, except for magnetic anomaly 5aa, on DNAG timescale, 12.92 Ma and on Cande and Kent [1992] timescale, 13.0 Ma.

Most of the segment boundaries lie above the rigid part of the subducting Juan de Fuca plate, but the southernmost boundary, where there is a slight SE jump in the volcanic front, may correspond to the postulated limit between the South Gorda and Juan de Fuca plates. Some of the other segment boundaries of the Cascadia arc are much more dramatic than this one. Thus from the geology of the upper plate alone, one would not interpret this location as a likely microplate boundary in the subduction zone.

\section{Middle America Trench: Deformation Above a Subducting Plate Boundary}

The Colima rift and its offshore extension, the Manzanillo Trough, constitute one of the best modern examples of upper plate deformation coincident with the presence of a plate boundary within a subduction zone (Figure 3). They lie within the North America plate, at a high angle to the trench, above the inferred location of the CocosRivera slab boundary, and extend from the Middle America trench to the volcanic arc (the Mexican Volcanic Belt or MVB). The Colima Rift is a distinct topographic low, striking just east of north, with $-1000 \mathrm{~m}$ of topographic relief on its western wall and a bit less on its eastern wall. Adjacent to it offshore, a depression in the upper slope of the trench (the Manzanillo Graben) produces an embayment in the trench axis. Together, the Colima Rift and the Manzanillo Graben separate the Jalisco block (on the northwest) from the Michoacan-Guerrero block (on the southeast) for a distance of $-260 \mathrm{~km}$. The Colima rift ends northward at the MVB in a junction with two other grabens defined by topographic lows and active normal and strike- slip faults, the Tepic-Zacoalco graben (to the west) and the Chapala and Citala Grabens (to the east). Active volcanoes continue eastward from here within the MVB across Mexico and westward along the Tepic-Zacoalco graben.

The Colima Rift and Manzanillo Graben are bounded by high-angle faults, but the geometry and structural expression of extension vary along strike within the grabens. The Colima rift is composed of three different structural basins from north to south [Allan et al., 1991]. The northern basin varies from 20 to $65 \mathrm{~km}$ in width, has $>2500 \mathrm{~m}$ of normal separation on its western bounding faults, and has extended by 1.5 to $3.3 \mathrm{~km}$ since $\sim 4$ to $5 \mathrm{Ma}$ [Allan, 1986]. East and west of the northern basin are minor N-S striking grabens. The central basin has a steep normal fault and substantial topographic relief on its western margin and contains three large volcanoes, the southernmost one of which (Volcán Colima) is presently active (Figure 3 ). The southern structural basin is a composite basin, $100 \mathrm{~km}$ wide, inferred to contain up to $8 \mathrm{~km}$ of sedimentary fill [Bandy et al., 1993]. Although evidence for significant or active extension in this region is debated [Serpa et al., 1992], normal faults striking $\mathrm{N}^{\circ} 0^{\circ} \mathrm{E}$ in the upper slope of the trench (the Manzanillo Graben) are active [Bourgois and Michaud, 1991; Bandy, 1992].

A variety of compositionally and spatially anomalous young volcanism occurs within the northern and central structural basins and along the bounding fault systems. The calc-alkaline volcanism found here is not surprising, as it is typical of subduction-related volcanic arcs. However, peralkaline and alkaline lavas, more typical of continental rift zones, have erupted in close proximity to and coeval with 
the calc-alkaline rocks [Allan et al., 1991]. Some of these compositions are similar to those found in the East African rift and are not known from any other subduction setting [Allan et al., 1991]. Volcanism also extends $120 \mathrm{~km}$ closer to the trench than is typical in the main MVB; Volcán Colima and numerous cinder cones have developed within $170 \mathrm{~km}$ of the trench. This spatially and compositionally anomalous volcanism is not confined to the Colima Rift. Within the Jalisco block, numerous small Plio-Quaternary volcanoes are found within grabens at similar distances from the trench [e.g., Wallace et al., 1992; Righter and Carmichael, 1992].

The main deposits that have accumulated in the Colima Rift since extension began in early Pliocene time are volcanic deposits from vents within the rift and off the main trend of the MVB. These include eruptive products of large calc-alkaline stratovolcanoes, calc-alkaline domes and cinder cones, small alkaline cinder or lava cones, and mudflow and debris avalanche deposits from the stratovolcanoes, some of which flowed all the way to the trench. Additional nonvolcanic deposits include lacustrine deposits from ephemeral lakes, alluvium, and gravels. The sedimentary fill in various parts of the rift ranges from $1 \mathrm{~km}$ to $8 \mathrm{~km}$ in thickness [Allan et al., 1991; Bandy et al., 1993]. These deposits have accumulated in a zone that varies from $-20 \mathrm{~km}$ to $-100 \mathrm{~km}$ in width. This structural and depositional association is unique with respect to the surrounding, mainly Cretaceous basement rocks. This association is the type that we would look for elsewhere, at a high angle to the trench or paleotrench, as evidence for the possible position of a microplate boundary within downgoing plates at a subduction zone.

The Rivera and Cocos plates, presumed to exist beneath this region, are unquestionably independent plates. Magnetic anomalies from ridge segments north and south of the Rivera transform fault yield demonstrably different Pacific-Cocos and Pacific-Rivera poles [DeMets and Stein, 1990; Bandy, 1992]. However, the boundary between the Rivera and Cocos plates, extending from the eastern end of the Rivera Transform Fault to the trench, is a complicated zone of deformation. The type and orientation of structures vary along strike and do not yield direct information on relative plate velocities. The pole of relative motion obtained by combining Cocos-Pacific and Rivera-Cocos data lies very close to this boundary, but its position has a large uncertainty. Any pole must be compatible with the observed extension between the Cocos and Rivera plates at the eastern end of their mutual boundary in the El Gordo Graben [Bandy, 1992; Bandy and Pardo, 1994] (Figure 3). The configuration of the subducted slab of the Rivera and Cocos plates is not well resolved. Seismicity suggests that the Cocos plate steepens toward the NW, reaching a dip of $50^{\circ}$ and a depth of $130 \mathrm{~km}$ beneath Volcán Colima [Pardo and Suarez, 1993]. However, existing data do not define the slab at depth farther west beneath the main part of the Jalisco block; this part of the Benioff zone is seismically much quieter than the Cocos-North America Benioff zone. Because of the lower seismicity of the Rivera slab, it is not known whether the Rivera plate slab connects to the Cocos plate slab, nor is it known at what depth these slabs underlie the MVB in the Jalisco region.
On the basis of marine magnetic anomalies of the adjacent Pacific seafloor [Lonsdale, 1991; Atwater and Severinghaus, 1989] and global plate reconstructions [e.g., Stock and Molnar, 1988], the evolution and locations of offshore plates in this region are fairly well understood. The southern end of the Pacific-North America plate boundary, corresponding to the northern end of the Middle America Trench (Figure 3), has occupied approximately the same position relative to North America since $-10 \mathrm{Ma}$. From 10 $\mathrm{Ma}$ to $5 \mathrm{Ma}$ this was the location of a triple junction between three major plates, the North America, Cocos, and Pacific. By $-5 \mathrm{Ma}$, owing to a progressive spreading center transfer causing the brief existence of the "Mathematician paleoplate" [Mammerickx et al., 1988, Williams and Lonsdale, 1993], the spreading segment just south of the Rivera transform fault relocated to within $-100 \mathrm{~km}$ of the trench [Stock, 1993a]. By this time, part of the Cocos plate north of this transform fault had begun to move independently of the main Cocos plate. This northern plate fragment became the modern Rivera plate. It is important to note that the position of the Cocos-Rivera-North America triple junction has not moved much with respect to the North America plate since its inception because subduction of both plates has been nearly orthogonal to the trench. In sharp contrast to the Cascadia subduction zone, the microplate boundary within the Middle America trench appears to have been influencing the geology of the overriding plate at about the same location for $-5 \mathrm{~m} . \mathrm{y}$. (5 $\mathrm{Ma}$ to present). This correlates with the $\sim 5 \mathrm{Ma}$ age for the oldest recognized volcanism within the main part of the Colima graben [Allan, 1986].

The Colima Graben-Manzanillo Graben extensional structures are generally viewed as an upper plate response to divergence between the Rivera and Cocos plates at depth within the subduction zone. However, there is continued disagreement regarding the motion of these oceanic plates relative to the overriding North America plate. Some authors have suggested that subduction of the Rivera plate is obliquely dextral and that subduction of the Cocos plate is normal to the trench; this would imply that the Jalisco block (within the North America plate but above the Rivera plate) is moving a few millimeters per year right laterally with respect to the rest of North America and that there may be an incipient jump of the Pacific-North America spreading center southeastward into the Colima Graben [e.g., Luhr and Carmichael, 1981; Luhr et al., 1985; Allan, 1986]. An alternative model in which subduction of the Rivera plate is normal to the trench and subduction of the Cocos plate is obliquely sinistral relative to North America implies that the Jalisco block is fixed to North America but that a coastal block in the Michoacán-Guerrero area is being displaced left laterally at a velocity of a few millimeters per year relative to North America [DeMets and Stein, 1990]. Current models of regional plate velocities [DeMets and Stein, 1990; Bandy, 1992] permit both possibilities, within the uncertainties. In either case the rate of subduction of the Cocos plate is faster than the rate of subduction of the Rivera plate, so that the component of Rivera-Cocos motion is dominantly strike slip along their mutual boundary. Regardless of which model proves to be correct, there is a striking correlation of upper plate structural disruption, as 
well as upper plate volcanism and consequent sedimentation, with the position of the Rivera-Cocos boundary.

In this case the presence of an (extensional) microplate boundary in the subduction zone has dramatic geological consequences. First, it correlates with a major, topographic low and series of basins associated with numerous active volcanoes of a variety of compositions in the overriding plate [Allan et al., 1991]. Second, the connection of this structure to grabens in the MVB, at a type of "triple junction," suggests that the differential movement of the subducted plates may be causing the detachment and lateral translation of a piece of the overriding North America plate in the forearc region.

\section{Neogene Microplates in the Subduction Zones of Western North America}

\section{Introduction}

The approach of the Pacific-Farallon ridge toward North America and the creation of the Pacific-North America transform margin resulted in the formation of two triple junctions, the Mendocino (between Pacific, North America, and North Farallon fragment) and the Rivera (between Pacific, North America, and South Farallon fragment) [Atwater, 1970]. Continued fragmentation of the Farallon plate created various, short-lived microplates in the subduction zone adjacent to both of these triple junctions, in turn, creating other triple junctions of different types along the margin (Figure 1). Magnetic anomaly patterns and bathymetric data, preserved offshore coastal California and Baja California, constrain the history of these microplates and have been most recently summarized by Lonsdale [1991], Atwater [1989], and Atwater and Severinghaus [1989]. The microplates identified thus far include, from oldest to youngest and from north to south, the Monterey (independent from $-30 \mathrm{Ma}$ to $-19 \mathrm{Ma})$, Arguello $(-20$ to -18 Ma), Guadalupe ( -20 to $-14 \mathrm{Ma}$ ), Magdalena (14 to 12 $\mathrm{Ma}$ ), and Rivera ( $-5 \mathrm{Ma}$ to present) (Figure 1).

These microplates did not always get completely subducted beneath North America. Dead ridges, symmetric magnetic anomaly patterns, and age of basement penetrated in ocean drill holes indicate that remnants of these microplates became sutured onto the Pacific plate and are still preserved. When these microplates died, they may have been larger than the areas presently preserved offshore. Pacific plate ocean floor (and presumably also fragments of dead ridges and oceanic crust belonging to microplates) may have been locally overridden by continental North America [Page and Brocher, 1993], although the importance of such processes is strongly debated [e.g., Nicholson et al., 1994; R. G. Bohannon and T. Parsons, submitted manuscript, 1994].

In order to examine the possible effects of these microplate boundaries on the tectonics of North America, we would like to know the location and timing of activity of these structures in the subduction zone. These can be constrained by the magnetic anomaly patterns [Lonsdale, 1991; Atwater, 1989; Atwater and Severinghaus, 1989; Klitgord and Mammerickx, 1982; Mammerickx and Klitgord, 1982].
The positions of these boundaries relative to North America and relative to geological observations on the $B$ aja California peninsula can then be estimated by using plate reconstructions. Three major ingredients are necessary in order to do this properly. First, one must remove the extension and strike-slip faulting in the Gulf of California, thereby returning Baja California to its early Miocene position relative to the shoreline of mainland Mexico. Second, one must move the Pacific plate into the appropriate past position relative to North America. Third, one must remove the deformation that occurred between the continental margin and the stable interior of North America (principally Basin and Range extension) since the time of interest. Although neither the configuration of the closed Gulf of California nor the reconstructions of the Pacific plate to North America is precisely known, if several assumptions are made and the uncertainties are included, then a reasonable reconstruction can be attempted [e.g., Stock and Hodges, 1989].

We use these techniques to obtain the constraints, discussed below, on the timing and positions of the microplate boundaries near Baja California. The reconstructions presented in this paper use the same plate circuit and the same closure of the Gulf of California as did Stock and Hodges [1989]. However, here we use an updated and more detailed version of the offshore magnetic anomalies and the microplate history [Lonsdale, 1991]. Also, Stock and Hodges [1989] did not attempt to remove late Tertiary extension within Mexico. They noted that this yielded a clearly unacceptable overlap of present Pacific seafloor and North American continental crust in some of their reconstructions. The Neogene extensional history of western Mexico is still too poorly known to accurately reconstruct Baja California and the Sonora-Sinaloa coast relative to the stable North America plate. Nevertheless, in our reconstructions we have removed the minimum amount of extension, in an ENE-WSW direction $(130 \mathrm{~km})$, that is needed to eliminate this overlap. This direction of extension is perpendicular to strike of Neogene normal faults in the Mexican Basin and Range province, many of which may have been active during the time period of these reconstructions [Henry and Aranda-Gomez, 1992]. This introduces an additional uncertainty into the reconstructions (see Figure 4 caption), but it is still smaller than the overall geographical extent of the features we are seeking (deformation related to presence of microplate boundaries). In order to reduce the uncertainties, it is vital to obtain the necessary geological data to accurately account for the Tertiary extension within mainland Mexico, but that task is beyond the scope of this paper.

\section{Murray and Morro Fracture Zones (Southern Boundary of the Monterey Plate)}

The southern edge of the Monterey plate was the Murray fracture zone (FZ) from the time of anomalies 9-7 and the Morro FZ thereafter, from -25 to $-19 \mathrm{Ma}$ (Figure $4 \mathrm{a}$ ). The obliquity of these fracture zones to the continental margin and to the coeval Pacific-Guadalupe FZs that were present farther south clearly shows that the Monterey plate was moving in a direction different than the region south of the 
Morro FZ. If spreading were symmetric, then net convergence is implied between the Monterey microplate and Guadalupe (or Arguello) plate to the south. However, it has been speculated [Lonsdale, 1991; Atwater, 1989] that the Monterey plate was "stagnant" and possibly was moving with the North America plate (see discussion by Nicholson et al. [1994] and R. G. Bohannon and T. Parsons (submitted manuscript, 1994)). If so, it seems likely that the Monterey-North America boundary may have been geometrically analogous to the modern Explorer-North America boundary, a complex transcurrent fault zone where there was little to no subduction of the Monterey plate beneath North America. In this case the microplate boundary might not induce deformation of the adjacent North America plate. The Monterey-Guadalupe (Arguello) convergence may thus have been accommodated entirely by internal deformation of the Monterey plate. Any effects due to the Monterey-Guadalupe boundary should be sought in the Continental Borderland region between Ensenada and the Vizcaíno Peninsula.

\section{Arguello FZ (Arguello-Guadalupe Plate Boundary)}

The southern boundary of the Arguello plate was the Arguello $\mathrm{FZ}$ from the time of anomalies 6 to $5 \mathrm{D}(20 \mathrm{Ma}$ to $18 \mathrm{Ma}$, Figure 4a). Slight offset of isochrons $5 \mathrm{E}$ and $5 \mathrm{D}$ immediately south of the Arguello FZ may be related to Arguello-Guadalupe motion, as the southern boundary of the Arguello microplate jumped farther south during the last few million years of its lifetime. Arguello-Pacific spreading was intermediate in direction and rate between Cocos-Pacific and Monterey-Pacific spreading. The configuration of the youngest known Arguello-Pacific anomalies (5E and 5D, 18.8 to $17.3 \mathrm{Ma}$ ) suggests that Arguello, also, was becoming stagnant (moving nearly with North America) [Atwater, 1989]. Its southern boundary would probably bave been entering the subduction zone offshore northern Baja California (Figures 4a and $4 \mathrm{~b}$ ). However, by analogy with the modern Explorer plate, at this point there may have been virtually no Arguello-North America convergence, so that this motion between Arguello and North America may have been largely transcurrent.

\section{Shirley FZ (Guadalupe-Cocos Plate Boundary)}

The Guadalupe-Cocos plate (Figure 1) had probably broken into northern (Guadalupe) and southern (Cocos) fragments by the time of anomaly $6(20.45 \mathrm{Ma}$ on the Decade of North American Geology (DNAG) timescale), judging from differences in spacing and orientation of anomalies $6 \mathrm{~A}$ and younger across the trace of the Shirley fracture zone [Lonsdale, 1991]. The ridge segments between the Pacific plate and the Guadalupe plate rapidly rotated anticlockwise into approximate parallelism with the trench, possibly due to pivoting subduction as described by Menard [1978] caused by stronger slab pull in the south due to its older plate age. This reoriented the fracture zones north of the Shirley FZ counterclockwise $10-15^{\circ}$ and increased their curvature (i.e., the local Euler pole moved closer to the region) relative to those south of the Shirley FZ. During this time the eastern counterpart of the Shirley FZ may have had a component of extension across it.
While the eastern counterpart to the Shirley FZ was an active microplate boundary, it would have intersected the subduction zone along Baja California Sur, from about the latitude of $\mathrm{La} \mathrm{Paz}$ at $-20 \mathrm{Ma}$ (Figure $4 \mathrm{a}$ ) to about the latitude of Loreto at $-12.5 \mathrm{Ma}$ (Figure $4 \mathrm{~d}$ ) when Guadalupe-Pacific spreading ceased. Given the $-150 \mathrm{~km}$ uncertainty in the plate reconstructions (parallel to the present coastline), any geologic effect on the overriding plate due to the presence of the Shirley FZ as a microplate boundary may be as far north as the latitude of Bahía Concepción in southern Baja California (Figure 4).

\section{Magdalena-Cocos Plate Boundary}

The Magdalena Rise, a series of en echelon bathymetric highs present south of the Shirley FZ along the length of Baja California, has been interpreted as a dead ridge-transform system of about the age of the Guadalupe Ridge, although directly relevant age data are lacking (Figure 4d) [Lonsdale, 1991]. The difference in orientation between the Magdalena Rise and the Cocos-Pacific magnetic anomalies farther south suggests that the Magdalena Rise was formed by spreading of the Pacific plate away from a separate microplate (Magdalena plate of Lonsdale [1991]) from $\sim 14 \mathrm{Ma}$ to $12.5 \mathrm{Ma}$ (Figure 4d). Thus an active Magdalena-Cocos boundary would have been entering the trench during this time interval. The Magdalena-Cocos-Pacific triple junction lay at the tip of a northward migrating offset north of the Clarion FZ (Figure 4d). Thus the Magdalena-Cocos boundary migrated north relative to the North America plate faster than did the Pacific plate. However, it remained entirely south of the latitude of Baja California. It would have intersected the Middle America Trench near Jalisco or possibly opposite the region that later became the mouth of the Gulf of California.

\section{Northern Edge of the Guadalupe Plate (Pacific-} Guadalupe Plate Boundary)

The northern edge of the Guadalupe plate must have been a microplate boundary from 20 to $12.5 \mathrm{Ma}$, but the precise geometry and location of this boundary relative to North America and Baja California probably varied (Figure 4). No dead oceanic ridge has been identified between the Arguello FZ and the northern end of the Soledad Ridge (Figures 4c and 4d). Rather, the youngest magnetic anomalies trend obliquely into the trench, getting younger southward. These represent the maximum ages of cessation of spreading [Atwater, 1970]. The youngest possible time of cessation of spreading could be a bit younger if magnetic anomalies have been overrun by the continent during later convergence. The northernmost possible position of this boundary was the Arguello FZ at $20 \mathrm{Ma}$ (Figure 4a). The boundary may have moved southward with time relative to the Pacific plate, and it could have been as far south as the northern end of the Soledad ridge at $12.5 \mathrm{Ma}$ when spreading ceased (Figure $4 \mathrm{~d}$ ). Thus this boundary could have lain anywhere from Ensenada southward and might have stayed in a relatively constant location, or it might have migrated southward as far as the Vizcaíno Peninsula by $12.5 \mathrm{Ma}$.

The Guadalupe-Pacific-North America triple junction present in this region, after the Arguello microplate became attached to Pacific at $\sim 17 \mathrm{Ma}$, would have connected northward with the Pacific-North America boundary, possibly rep- 
resented by a set of "fossil spreading centers" tentatively identified within the Southern Borderland Rift, from the Soledad Ridge northward [see Crouch and Suppe, 1993]. If they reflect Pacific-North America motion, then they indicate that the Guadalupe plate was south of this position at the time they were active. However, they have not been dated.

From these data it appears that the eastern counterparts of the Arguello FZ, the Shirley FZ, possibly the Guadalupe FZ, and structures in the zone between the Arguello FZ and the northern Soledad Ridge may all have been active as microplate boundaries west of Baja California at various times during the Miocene. However, we find no evidence that they induced any throughgoing deformation zones in the overriding plate between the trench and the volcanic arc (that is, within the crust of Baja California before it separated from the North America plate). After these plates "died" by becoming attached to the Pacific plate there were strong effects along the continental margin in the vicinity of the old trench (the California Continental Borderland) but not extending east into the region of the old volcanic arc [Nicholson et al., 1994; R. G. Bohannon and T. Parsons, submitted manuscript, 1994]. We describe the principal evidence for geological stability of much of the Baja California Peninsula during Miocene time, as follows: continuity and lack of deformation of the Miocene subduction-related volcanic arc and continuity and lack of deformation of pre-Miocene sedimentary rocks between the volcanic arc and the trench.

\section{Guadalupe FZ (Boundary Within the Guadalupe Plate)}

Pacific-Guadalupe spreading ceased along the Guadalupe Ridge, between the Shirley FZ and the Guadalupe FZ, during chron 5A (12.5 Ma on the DNAG timescale, Figure 4d). This ridge death caused a $220-\times 220-\mathrm{km}$ fragment to become sutured to the Pacific plate. The Soledad Ridge, another small $(120 \mathrm{~km}$ long) topographic high north of the Guadalupe $\mathrm{FZ}$, is interpreted as a similar rifted volcanic ridge that may have died at the same time (Figure 4d) [Lonsdale, 1991]. The magnetic anomalies immediately adjacent to the Soledad Ridge are difficult to interpret and look different from those surrounding the Guadalupe Ridge to the south. This suggests a different spreading history across the boundary or to a zone of diffuse deformation within the region north of the Guadalupe FZ. If the Guadalupe $F Z$ or a diffuse zone to the north of it had been active as a miGuadalupe FZ, possibly corresponding to another microplate croplate boundary, then it would have been only for a relatively short time (1-2 m.y.) and it would have intersected the subduction zone somewhere within $-100 \mathrm{~km}$ (parallel to the margin) of the Vizcaíno Peninsula.

\section{Geologic Stability of Baja California During Miocene Time}

Geometry and Geochemistry of the Early to Middle Miocene Volcanic Arc in Baja California

Calc-alkaline volcanic rocks and related sedimentary rocks of early to middle Miocene age are exposed along much of the length of the Baja California peninsula (Figure
5). They correspond to the 17 to $22 \mathrm{Ma}$ andesite belt of Gastil et al. [1975] and in southern Baja California they are often referred to as the "Comondú Formation." (See Hausback [1984] for a detailed discussion of the stratigraphic nomenclature of volcanic and sedimentary rocks of this age in Baja California Sur.) In Baja California Sur some volcanic vents crop out along the eastern side of the peninsula; others are inferred to have lain farther east and are now offshore. Numerous $\mathrm{K}$-Ar ages constrain the vents to be from -24 to $12 \mathrm{Ma}$ in age [Hausback, 1984; Sawlan and Smith, 1984; Sawlan, 1991]. These rocks range from calc-alkaline andesite to rhyolite, but are dominantly andesite, and have typical subduction-related chemical signatures [e.g, Sawlan, 1991]. No known rift-related volcanic rocks of this age have been described.

In southern Baja California these rocks are generally flat lying and undeformed, except near the Gulf of California where they have been affected by normal faulting and local, soft sediment deformation [e.g., Hausback, 1984]. Regional geological studies [McLean, 1988; McLean et al., 1985, 1987; Sawlan and Smith, 1984; Fenby and Gastil, 1991] show this lack of deformation clearly and make it difficult to postulate the presence of any throughgoing Miocene fault zones or grabens crossing the Baja California peninsula at this latitude. The only major throughgoing structure is the north striking graben along the $\mathrm{La} \mathrm{Paz}$ fault zone [Hausback, 1984] which is attributed to left slip during late Miocene extension at the mouth of the Gulf of California [Lonsdale, 1991]. Elsewhere, the early-to-middle Miocene volcanic belt of southern Baja California is surprisingly flat lying and undeformed.

In northern Baja California the rocks of the early to middle Miocene volcanic arc do not crop out continuously. North of $28^{\circ} \mathrm{N}$, they are only discontinuously exposed, owing partly to erosional removal and to burial by younger volcanic rocks. Dacite and andesite vents in this age range are found beneath late Miocene to Pliocene rocks at $30^{\circ} 16.5^{\prime} \mathrm{N}, 16 \mathrm{Ma}$ (A. Martín-Barajas et al., Arc-rift transition volcanism in the Puertecitos Volcanic Province, northeastern Baja California, Mexico, submitted to Geological Society of America Bulletin, 1994) and at $30^{\circ} 28^{\prime} \mathrm{N}$, 17-20 Ma [Stock et al., 1991]. Other dacite-andesite vents of unknown but probably similar age occur at $31^{\circ} 27^{\prime} \mathrm{N}$ (J. Lee, unpublished mapping, 1993) (Figures $4 \mathrm{~b}$ and 4c). Relict volcanic necks farther west at this latitude, such as Pico Matomí and Pico Los Heme, are speculated to also be within this age range [Gastil et al., 1975] but have not been dated. Related mass flow deposits and epiclastic rocks, mapped as fluvial conglomerates by Gastil et al. [1975] and labeled "Comondú Formation" by Dorsey and Burns [1994], crop out in the Sierra Juárez area (locality B, Figure 5) [Miller et al., 1992; Lee and Miller, 1994] and from the southern end of the Sierra San Pedro Mártir (locality C, Figure 5) [Stock, 1989] to $29^{\circ} 40^{\prime} \mathrm{N}$ (locality A, Figure 5) [Gastil et al., 1975]. These volcaniclastic sedimentary rocks are extensive on the Baja California peninsula and can thus be used as a guide to the location of the early to middle Miocene volcanic belt and for recognition of syn- or postvolcanic deformation.

Insofar as is known from existing geological mapping in Baja California, the western exposures of these arc-related deposits are not significantly deformed along the length of 


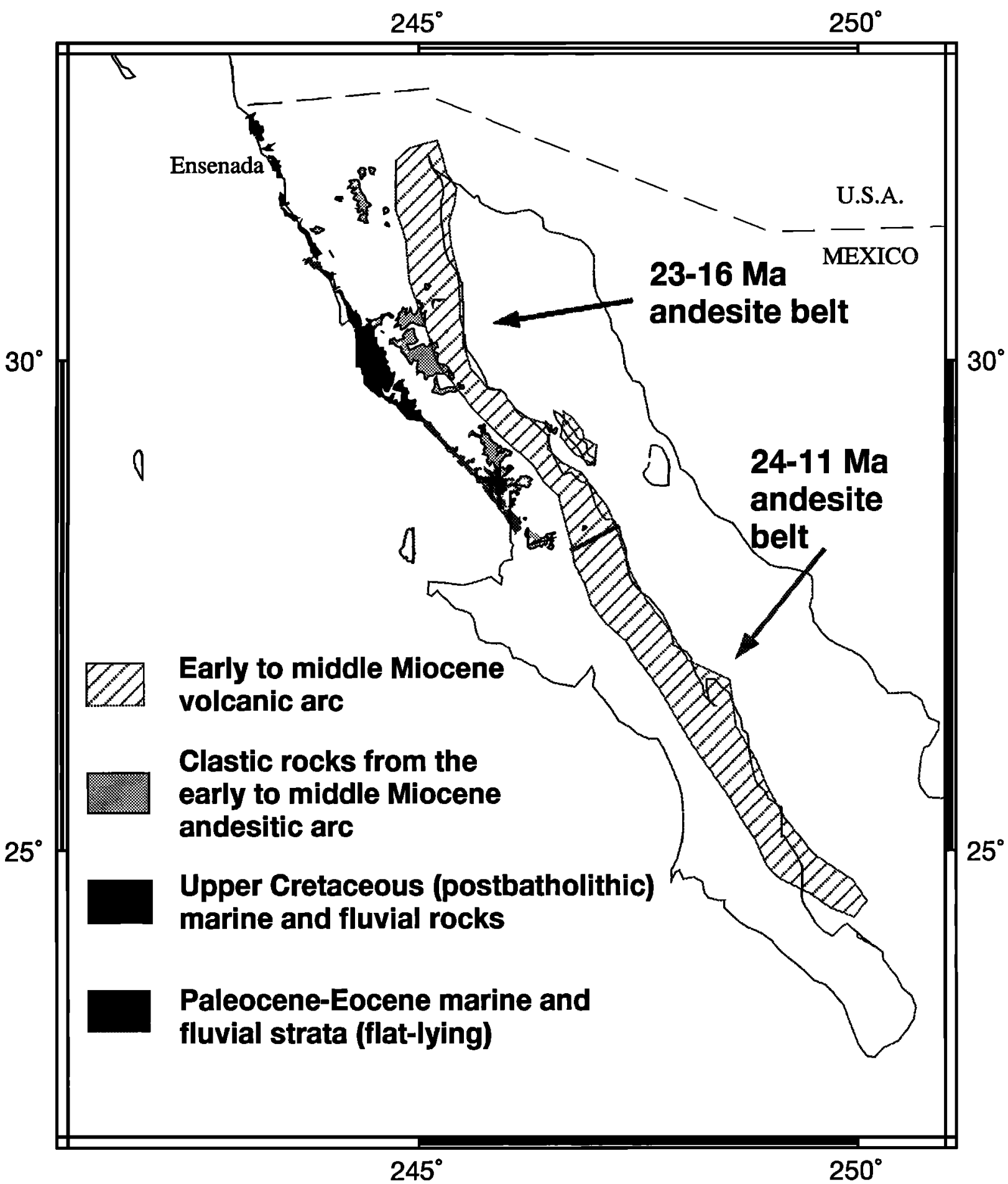

Figure 5. Distribution of pre-Miocene flat-lying strata on the Baja California Peninsula [from Gastil et al., 1975; Fenby and Gastil, 1991]; early to middle Miocene volcanic rocks of the andesite belt, inferred to be related to subduction [from Sawlan, 1991; Gastil et al., 1979]; and early to middle Miocene sedimentary rocks of the clastic apron of the andesitic arc [from Gastil et al., 1975; Dorsey and Burns, 1994; Stock, 1993b]. Localities A, B, and C are discussed in the text. The lack of significant deformation recognized in any of these units west of the Main Gulf Escarpment precludes the existence of any major zones of early to middle Miocene deformation reaching from the volcanic arc westward to the former trench. 
the peninsula (some $1500 \mathrm{~km}$ ). They are generally flat lying west of the Gulf of California extensional province [e.g., Dorsey and Burns, 1994]. Their outcrop pattern is fairly linear in map view, implying no big excursions of contemporaneous volcanism to locations much closer to the trench. Significant faulting and tilting has affected them within the Gulf of California extensional province, but where this deformation has been dated, it postdates subduction and is attributed to extensional faulting accompanying the opening of the Gulf of California [e.g., Stock and Hodges, 1989; Lee and Miller, 1994].

\section{Paleocene to Eocene Sedimentary Rocks Along the Pacific Coast of the Baja California Peninsula}

Tertiary sedimentary rocks crop out west of and/or beneath the deposits of the Miocene volcanic arc along much of the western side of the northern Baja California Peninsula. These Paleocene to Eocene [Gastil et al., 1975] marine and fluvial deposits are flat lying to very shallowly west dipping $\left(55^{\circ}\right)$ and unconformably overlie Cretaceous rocks. These rocks are found continually along the coast from $28^{\circ} \mathrm{N}$ to $29^{\circ} 30^{\prime} \mathrm{N}$ and in a few isolated patches farther north $\left(30^{\circ} \mathrm{N}, 31^{\circ} \mathrm{N}\right)$ (Figure 5). These flat-lying rocks can be followed eastward as far as the Main Gulf Escarpment. In between these exposures and north to the $U$. S. border there are continuous exposures of postbatholithic, Upper Cretaceous, marine and fluvial strata [Gastil et al., 1975]. Within these coastal exposures there are no mapped structures that could be attributed to Miocene grabens at high angles to the west coast of the Baja California peninsula. There are no major thicknesses of Miocene sedimentary rocks, nor is there any evidence of significant deformation of the older rocks. Thus we conclude that in northern Baja California the available geological evidence supports structural coherence of the peninsula between Ensenada and La Paz. We can find no evidence for any major structural breaks extending from the early to middle Miocene volcanic arc into the region of the former trench.

\section{Discussion}

\section{Plate Configurations During Waning Subduction}

The geological data from the Baja California peninsula suggest that the microplate boundaries present west of Baja California during the final stages of Neogene subduction had no major effect reaching into the interior (that is, from the trench to the volcanic arc) of the overriding plate. There appears to be no structural or deformational pattern that would correlate with these boundaries; rather, the PaleoceneEocene sedimentary rocks along the west coast of the peninsula are surprisingly undisturbed, and within the middle Miocene volcanic arc and related sedimentary rocks to the west, no major structural discontinuities have been recognized. The level of geological knowledge in many of these areas is still reconnaissance in nature, but nevertheless, if a structure analogous to the present Colima Graben had devel- oped on the Baja California peninsula owing to these microplate boundaries, then it should be visible in the existing geological data. The lack of any such structure and the final spreading histories of these microplates with the Pacific plate resemble the situation at the Juan de FucaGorda boundary or the Juan de Fuca-Explorer boundary, not the Rivera-Cocos boundary. The boundaries between these microplates may have been, in some cases, zones of diffuse deformation and high strain within the oceanic microplates, rather than discrete structural boundaries. (Collection of further marine geophysical information over the last remaining seafloor of these microplates might help to resolve this issue.)

In addition, the direction of the last stages of spreading of the Arguello and Monterey microplates from the Pacific plate suggests that they were adopting the motion of the larger North America plate [Atwater, 1989; R. G. Bohannon and T. Parsons, submitted manuscript, 1994], in much the same manner that the Explorer plate is moving nearly with North America at present [Rohr et al., 1993]. If so, subduction of these two plate fragments beneath western North America might have effectively stopped when these microplates were born and the spreading direction changed, several millions of years before the microplates actually ceased to exist. Presumably, if subduction of these plate fragments had stagnated, then their mutual boundary would not have gone very far down the trench and hence would not have been likely to cause much deformation of the overlying North America plate.

The orientation and magnetic anomalies of the Guadalupe Rise indicate that the Guadalupe plate did not adopt the motion of the North America plate. Rather, it was still converging with the North America plate at the time PacificGuadalupe spreading stopped. Nevertheless, the differential motion across the Shirley FZ (the southern boundary of the Guadalupe plate) may have been fairly small, except for the last few million years of its existence, when the ridge orientations north and south of the Shirley FZ appear to diverge. During this stage of plate motions we might expect some effect of the Shirley Transform's eastern counterpart on the geology of the overriding plate. None is known, however. This raises the possibility that (1) the eastern counterpart of the Shirley Transform corresponded to a zone of diffuse deformation between the subducting Guadalupe and Cocos/Magdalena plates or (2) the eastern counterpart of the Shirley Transform fault was a finite structure, but it swept along the subduction zone at a rate that was too fast to affect the overriding plate.

\section{Styles of Microplate Death}

All of the microplates discussed above (Monterey, Arguello, Guadalupe, and Magdalena plates) became attached to the Pacific plate when their ridge boundaries with the Pacific plate stopped spreading. By this process the Pacific-North America strike-slip margin jumped progressively southward. After becoming sutured to the Pacific plate some of the former microplates may have dragged pieces of continental material with them [Nicholson et al., 1994; R. G. Bohannon and T. Parsons, submitted manuscript, 1994], transferring bits of continental North 
America onto the Pacific plate and moving the Pacific-North America strike-slip zone east with time. However, this deformation was limited to areas west or north of the present Baja California Peninsula (i.e., the Continental Borderland). The peninsula appears to be quite coherent and intact. Deformation in the borderland did not reach all the way from the trench into the volcanic arc but was restricted to a zone within $-100 \mathrm{~km}$ of the trench (e.g., R. G. Bohannon and T. Parsons, submitted manuscript, 1994).

None of these microplates became attached to the North America plate. This is especially surprising in the case of the northern (Arguello and Monterey) plates, which were moving nearly with North America at the time they died (see also R. G. Bohannon and T. Parsons [submitted manuscript, 1994]). These relations could be explained if during the final stages of existence of these microplates, Pacific-North America motion were obliquely compressive relative to the Monterey-Pacific and Arguello-Pacific transform faults. Such geometry could have sheared off these young oceanic plates at the continental margin, so that these plates ceased spreading relative to and became sutured to the Pacific plate. However, such a scenario must remain highly speculative until the Pacific-North America plate motion history is known at resolution high enough to compare directions of relative motion at $\sim 1-\mathrm{m}$.y. time steps. This is not possible at the present time.

These observations lead to speculation about the eventual fates of the Gorda microplate (or South Gorda deformation zone, Figure 2) and of the Rivera plate (Figure 3). Much will depend on the future velocity of the Pacific plate relative to the surrounding plates. The Gorda microplate is already deforming because its southern boundary, the Mendocino Transform, is constrained by the geometry of the larger Pacific plate to the south. If the Gorda microplate does become fixed to North America, then the Gorda ridge will be free to reorient into the correct configuration for Pacific-North America spreading, but the southern boundary of the Gorda microplate (the Mendocino transform fault) will then become transpressive because of its orientation with respect to the Pacific-North America plate motion vector. If the Pacific-North America plate motions maintain their overall orientation, then it seems more likely that this small deforming region would be sheared off, perhaps along the paleotrench, in an event that would abruptly extend the San Andreas fault from the Mendocino triple junction along the present trench up to its junction with the Blanco fracture zone. Once such shearing occurs, the Gorda fragment would end up attached to the Pacific plate, by ridge death, just as in the case of the Monterey and Arguello microplates.

As noted earlier, the Rivera plate may be strongly coupled to the overriding Jalisco block. Others [e.g., Luhr and Carmichael, 1981] have suggested that both of these blocks are in the process of becoming attached to the Pacific plate as the East Pacific Rise jumps into the North American continent at the location of the Colima Rift. This would conflict with the inferences from global plate motions that Rivera-North America velocity is probably small [Bandy and Pardo, 1994; DeMets and Stein, 1990] and that, in fact, Rivera may be stagnating and slowly becoming attached to the overriding North America plate. Final reconciliation of these two points of view must await more precise kinematic data on relative plate and block motions from the RiveraJalisco-North America region. However, the available data suggest that the motion of Rivera is intermediate between that of North America and that of Cocos, permitting the possibility that the Rivera plate is slowly becoming attached to the North America plate.

Whether the Rivera plate can fully attach and then remain attached to the North America plate for any length of time will depend on the interplay between plate boundaries and relative plate motions in the region of the present RiveraPacific boundary (the Rivera Transform fault, Figure 3). If this fault is reasonably optimally oriented parallel to or transtensive with respect to future North America-Pacific motion, then the Rivera plate may be able to suture to North America. However, if this boundary becomes transpressive, then the resulting deformation and shear may redetach the Rivera fragment from the North America plate and strand it permanently as part of the Pacific plate.

If the Rivera plate is able to attach to the North America plate, then it is extremely important as a possible analogy to past plate motions. The setting where a ridge-transformtrench triple junction is migrating laterally along a trench and the trench is getting shorter provides a mechanism for suturing oceanic plate material to the formerly, entirely continental, overriding plate. In particular, it provides a mechanism by which the mouth of a continental rift (in this case the Pacific-North America rift in the Gulf of California) can contain magnetic anomalies that were not formed by the same plate pair but, rather, by a different spreading system (in this case, Pacific-Rivera spreading) (Figure 3).

A similar plate configuration with microplate tectonics in a shortening subduction zone appears to have existed during early rifting of the Campbell Plateau-Chatham rise region from West Antarctica during late Cretaceous time. The Aluk plate was being subducted beneath the west Antarctic margin, and the Pacific-Aluk ridge was approaching the trench, in a manner analogous to that of the Cocos plate and the East Pacific Rise in the Middle America trench today. In the wake of the ridge-trench interaction, continental material was transferred from West Antarctica to the Pacific plate (analogous to the transfer of Baja California to the Pacific plate). Despite the fact that the continental material adjacent to this rift system belongs to the Pacific and Antarctica plates the oldest magnetic anomalies in the mouth of the rift system were not formed by Pacific-Antarctic spreading but, rather, by spreading between the Pacific plate and a fragment that probably broke off the Aluk plate (labeled "Bellingshausen" by Stock and Molnar [1987]). The Bellingshausen plate may have continued to converge with West Antarctica, even after rifting began, analogous to the modern Rivera plate within the Middle America trench. Further studies of the region of the Bellingshausen plate will help to clarify the degree to which this analogy is valid. From our detailed knowledge of the microplate kinematics along the western margin of the North America plate we expect that the West Antarctic margin may, in future studies, reveal evidence for continued breakup of the Aluk plate and possible preservation of microplate remnants (as well as their geological effects on the continent) along the former trench there. 


\section{Conclusions}

1. Subduction of active microplate boundaries of nonridge type sometimes correlates with deformation of the overriding continental plate (e.g., formation of grabens), anomalous volcanism above the microplate boundary in the subduction zone, and spatial or geochemical variations in the subduction-related volcanic arc. Some active microplate boundaries (e.g., Rivera-Cocos) exhibit many or all of these effects, whereas others (e.g., Juan de Fuca-Gorda, Juan-deFuca-Explorer) exhibit none of them. We recognize these as two end-member plate tectonic settings as follows: microplates whose boundaries induce substantial deformation of the overlying plate and microplates whose boundaries leave no apparent trace in the geology of the overlying plate. The difference between these may be due to the trench-parallel velocity component of the microplate boundary and to the degree of coupling between the various plates in a given region. It may also depend on the size and age distribution of the microplate being subducted since a very small microplate with insufficient slab-pull force may stagnate or attach itself mainly to the overriding plate.

2. The Monterey, Arguello, Guadalupe, and Magdalena microplates were present in the subduction zone west of Baja California at various times from 20 to $12.5 \mathrm{Ma}$. Their past locations and relative motions can be constrained by global plate reconstructions. Paleocene through Miocene rocks are extensively exposed in western Baja California in the region above the former microplate boundaries and are flat lying and undeformed. More geological data may reveal some subtle details, but existing data suggest that these plate boundaries did not have any major effect on the geology of the overriding plate. Thus they were more likely to have been of the Juan de Fuca-South Gorda or Juan de FucaExplorer type than of the Rivera-Cocos type. If internal deformation occurred within these microplates, then the existing level of marine surveying is still too sparse to identify it.

3. The ultimate fate of the microplates in the subduction zone may be strongly dependent on local plate geometries relative to changes in motion between the major plates of the region. Although all of these microplates died by transfer onto the Pacific plate, the modern Rivera plate may be an exception; it may be in the process of becoming transferred onto the North America plate. If so, this is the only known modern example of a process, inferred elsewhere from the geological record (e.g., West Antarctic margin and Bellingshausen-Pacific spreading), by which a microplate generates magnetic anomalies in the mouth of a rift while still being subducted beneath one of the bounding continental plates of the rift. If this microplate later stops subducting, then the seafloor it created may be later mistaken for seafloor generated by spreading between the two surrounding continental plates during the early stages of rifting.

Acknowledgments. This work was supported by NSF grant EAR-9296102. We thank Bob Bohannon and Don Argus for helpful reviews. Contribution 5437, Caltech Seismological Laboratory.

\section{References}

Allan, J., Geology of the Northern Colima and Zacoalco grabens, southwest Mexico: Late Cenozoic rifting in the Mexican Volcanic Belt, Geol. Soc. Am. Bull., 97, 473-485, 1986.

Allan, J., S. Nelson, J. Luhr, I. S. E. Carmichael, M. Wopmat, and P. Wallace, PlioceneHolocene rifting and associated volcanism in southwest Mexico, in: The Gulf and Peninsular Provinces of the Californias, edited by J. Dauphin and B. Simoneit, $A A P G$ Mem. 47, 425-445, 1991.

Atwater, T., Implications of plate tectonics for the Cenozoic evolution of western North America, Geol. Soc. Am. Bull., 81, 3513$3536,1970$.

Atwater, T., Plate tectonic history of the northeast Pacific and western North America, in The Eastern Pacific Ocean and Hawaii, Geol. of North Am., vol. N, pp. 2172, edited by E. L. Winterer, D. M. Hussong, and R. W. Decker, Geological Society of America, Boulder, Colo., 1989.

Atwater, T. M., and J. P. Severinghaus, Tectonic maps of the North Pacific, in The Eastem Pacific Ocean and Hawaii, Geol. of North Am., vol. N, edited by E. L. Winterer, D. M. Hussong, and R. W. Decker, Pp. 1520, Geological Society of America, Boulder, Colo., 1989.
Bandy W. L., Geological and geophysical investigation of the Rivera-Cocos plate boundary; Implications for plate fragmentation. Ph.D. thesis, Univ. of Tex., Austin, 1992.

Bandy, W. L., and M. Pardo, Statistical examination of the existence and relative motions of the Jalisco and southern Mexico blocks, Tectonics, 13, 755-768, 1994.

Bandy, W. L., C. A. Mortera-Gutierrez, and J. Urrutia-Fucugauchi, Gravity field of the southern Colima Graben, Mexico, Geofis. Int., 32(4), 561-567, 1993.

Bourgois, J., and F. Michaud, Active fragmentation of the North America plate and the Mexican triple junction area off Manzanillo. Geo. Mar. Lett., 11, 59-65, 1991.

Cande, S. C., and D. V. Kent, A new geomagnetic polarity time scale for the late Cretaceous and Cenozoic, J. Geophys. Res., 97, 13,917-13,951, 1992.

Crouch, J. K., and J. Suppe, Late Cenozoic tectonic evolution of the Los Angeles basin and inner California borderland: A model for core complex-like crustal extension, Geol. Soc. Am. Bull, 105, 1415-1434, 1993.

DeMets, D. C., and S. Stein, Present-day kinematics of the Rivera plate and implications for tectonics in southwestern
Mexico. J. Geophys. Res., 95, 21,93121,948, 1990.

DeMets, D. C., R. G. Gordon, D. F. Argus, and S. A. Stein, Current plate motions, Geophys. J. R. Astron. Soc., 101, 425-478, 1990.

Dorsey, R. J., and B. Burns, Regional stratigraphy, sedimentology, and tectonic significance of Oligocene-Miocene sedimentary and volcanic rocks, northern Baja California, Mexico, Sediment. Geol., 88, 231-251, 1994.

Fenby, S. S., and R. G. Gastil, Geologic-tectonic map of the Gulf of California and surrounding areas, in The Gulf and Peninsular Provinces of the Californias, edited by J. P. Dauphin and B. R. T. Simoneit, AAPG Mem., 47, 79-83, 1991.

Gastil, R. G., R. P. Phillips, and E. C. Allison, Reconnaissance geology of the state of Baja California, Mem. Geol. Soc. Am., 140, 170 Pp., 1975.

Gastil, R. G., D. Drummenacher, and J. Minch, The record of Cenozoic volcanism around the Gulf of California, Geol. Soc. Am. Bull., 90, 839-857, 1979.

Goldfinger, C., L. D. Kulm, R. S. Yeats, B. Appelgate, M. E. MacKay, and G. F. Moore, Transverse structural trends along the Oregon convergent margin: Implications for 
Cascadia earthquake potential and crustal rotations, Geology, 2O(2), 141-144, 1992.

Guffanti, M., and C. S. Weaver, Distribution of Late Cenozoic volcanic vents in the Cascade Range: Volcanic arc segmentation and regional tectonic considerations, J. Geophys. Res., 93, 6513-6529, 1988.

Hausback, B. P., Cenozoic volcanic and tectonic evolution of Baja California, Mexico, in Geology of the Baja California Peninsula, edited by V. A. Frizzell Jr., Publ. 39, pp. 219-236, Soc. Econ. Paleontol. Mineral., Paf. Sect., Bakersfield, Calif., 1984.

Henry, C. D., and J. Aranda-Gomez, The real southern Basin and Range: Mid to lateCenozoic extension in Mexico, Geology, 20, 701-704, 1992.

Klitgord, K. D., and J. Mammerickx, Northern East Pacific Rise: Magnetic anomaly and bathymetric framework, J. Geophys. Res. 87, 6725-6750, 1982.

Lee, J., and M. M. Miller, Middle Miocene extension in the Gulf Extensional Province, Baja California Mexico, Geol. Soc. Am. Abstr. Programs, 26, A65, 1994.

Lonsdale, P., Structural patterns of the Pacific floor offshore of Peninsular California, The Gulf and Peninsular Provinces of the Californias, edited by J. P. Dauphin, and B. R. T. Simoneit, AAPG Mem., 47, 87-125, 1991.

Luhr, J. F., and I. S. E. Carmichael, The Colima volcanic complex, Mexico, II, LateQuaternary cinder cones: Contrib. Mineral. Petrol., 76, 127-147, 1981.

Luhr, J. F., S. A. Nelson, J. F. Allan, and I. S. E. Carmichael, Active rifting in southwestern Mexico: Manifestations of an incipient eastward spreading-ridge jump, Geology, 13, 54-57, 1985.

Mammerickx, J., and K. D. Klitgord, Northern East Pacific Rise: Evolution from 25 m. y. B. P. to the present, J. Geophys. Res., 87, 67516759,1982

Mammerickx, J., D. F. Naar, and R. L. Tyce, The Mathematician paleo-plate, J. Geophys. Res., 93, 3025-3040, 1988.

Martín-Barajas, A., and J. M. Stock, Estratigrafía y petrología de la secuencia volcánica de Puertecitos, Noreste de Baja California: Transición de un arco volcánico a un rift, in Contribuciones a la Tectónica del Occidente de México, Monogr. 1, edited by L.A. Delgado-Argote and A. MartínBarajas, pp. 66-89, Mexican Geophysical Union, Ensenada, 1993.

McLean, H., Reconnaissance geologic map of the Loreto and part of the San Javier quadrangles, Baja California Sur, Mexico, U. S. Geol. Surv. Misc. Field Stud. Map, $M F-2000,1988$.

McLean, H., B. P. Hausback, and J. H. Knapp, Reconnaissance geologic map of part of the San Isidro Quadrangle, Baja California Sur, Mexico, U. S. Geol. Surv. Misc. Field Stud. Map, MF-1799, 1985.
McLean, H., B. P. Hausback, and J. H. Knapp, The geology of west-central Baja California Sur, Mexico, U. S. Geol. Sunv. Bull., I579, 16 pp., 1987.

Menard, H. W., Fragmentation of the Farallon plate by pivoting subduction, J. Geol., 86, 99-110, 1978.

Miller, M. M., J. Lee, and R. E. Crippen, Cenozoic structural development of the southeastern Sierra Juarez range fault, Northeastern Baja California, Geol. Soc. Am. Abstr. Programs, 24(5), 71, 1992.

Nicholson, C., C. Sorlien, T. Atwater, J. Crowell, and B. Luyendyk, Microplate capture, rotation of the Western Transverse Ranges, and initiation of the San Andreas Transform as a low-angle fault system, Geology, 22(6), 491-495, 1994.

Page, B. M., and T. M. Brocher, Thrusting of the Central California margin over the edge of the Pacific plate during the transform regime, Geology, 21, 635-638, 1993.

Pardo, M., and G. Suárez, Steep subduction geometry of the Rivera Plate beneath the Jalisco block in western Mexico, Geophys. Res. Lett., 20, 2391-2394, 1993.

Riddihough, R., Gorda plate motions from magnetic anomaly analysis, Earth Planet. Sci. Lett., 5I, 163-170, 1980.

Riddihough, R., Recent movements of the Juan de Fuca plate system, J. Geophys. Res., 89, 6980-6994, 1984.

Righter, $\mathbf{K}$, and I. Carmichael, Hawaiites and related lavas in the Atenguillo graben, Western Mexican Volcanic Belt, Geol. Soc. Am. Bull., 104, 1592-1607, 1992.

Rohr, K. M. M. R. W. Embley, K. Furlong, and C. Lowe, Sea Beam Survey of Queen Charlotte Triple Junction, Eos Trans. AGU, 74(43), Fall Meeting suppl., 593, 1993.

Sawlan, M. G., Magmatic evolution of the Gulf of California rift, in The Gulf and Peninsular Provinces of the Californias, edited by J. P. Dauphin and B. R. T. Simoneit, AAPG Mem. 47, 301-375, 1991.

Sawlan, M. G., and J. G. Smith, Petrologic characteristics, age and tectonic setting of Neogene volcanic rocks in northern Baja California Sur, Mexico, in Geology of the Baja California Peninsula, edited by V. A. Frizzell Jr., Publ. 39, pp. 237-251, Soc. Econ. Paleontol. Mineral., Pac. Sect., Bakersfield, Calif., 1984.

Serpa, L., S. Smith, C. Katz, C. Skidmore, R. Sloan, and T. Pavlis, A geophysical investigation of the southern Jalisco block in the State of Colima, Mexico, Geofis. Int., 31, 475-492, 1992.

Silver, E. A., Tectonics of the Mendocino Triple Junction, Geol. Soc. Am. Bull., 82, 2965-2978, 1971.

Smith, S. W., J. S. Knapp, and R. C. McPherson, Seismicity of the Gorda plate, structure of the continental margin, and an eastward jump of the Mendocino triple junction, $J$. Geophys. Res., 98, 8153-8171, 1993.

Stock, J. M., Sequence and geochronology of
Miocene rocks adjacent to the Main Gulf Escarpment: southern Valle Chico, Baja, California, Mexico, Geofis. Int., 28-5, 851896, 1989.

Stock, J. M., Tectónica de placas y la evolución del bloque Jalisco, México, Bol. 13(3), pp.39, Unión Geofís. Mex., Ensenada, 1993a.

Stock, J. M., The geology of southern Valle Chico and adjacent regions, Baja California, Mexico, Map and Chart Ser., MCH-076, Geol. Soc. of Am., Boulder, Colo., 1993b.

Stock, J. M., and K. V. Hodges, Pre-Pliocene extension around the Gulf of California and the transfer of Baja California to the Pacific plate, Tectonics, 8, 99-115, 1989.

Stock, J. M., and P. Molnar, Revised early Tertiary history of plate motion in the Southwest Pacific, Nature, 325, 495-499, 1987.

Stock, J. M., and P. Molnar, Uncertainties and implications of the late Cretaceous and Tertiary position of North America relative to the Farallon, Kula, and Pacific plates, Tectonics, 7, 1339-1384, 1988.

Stock, J. M., A. Martin, F. Suarez, and M. M. Miller, Miocene to Holocene extensional tectonics and volcanic stratigraphy of NE Baja California, Mexico, in Geological Excursions in Southern Califormia and Mexico, Guideb. for $1991 \mathrm{Geol}$. Soc. of Am. Annu. Meet., edited by M. J. Walawender and B. B. Hanan, pp. 44-67, San Diego State University, San Diego, Calif., 1991.

Wallace, P., I. S. E. Carmichael, K. Righter, and T. A. Becker, Volcanism and tectonism in western Mexico: A contrast of style and substance, Geology, 20, 625-628, 1992.

Williams, K., and P. Lonsdale, Rifting of oceanic lithosphere during growth of the south Mathematician Microplate, Eos Trans. $A G U$, 74(43), Fall Meeting suppl., 605, 1993.

Wilson, D. S., A kinematic model for the Gorda deformation zone as a diffuse southern boundary of the Juan de Fuca plate, $J$. Geophys. Res., 91, 10,259-10,269, 1986.

Wilson, D. S., Deformation of the so-called Gorda plate, J. Geophys. Res., 94, 3065 . 3075, 1989.

Wilson, D. S., Confidence intervals for motion and deformation of the Juan de Fuca plate, J. Geophys. Res., 98, 16,053-16,071, 1993.

Wood., C. A., and J. Kienle (Eds.), Volcanoes of North America: United States and Canada, Cambridge University Press, New York, 1990.

J. Lee, Geology Department, Central Washington University, Ellensburg, WA 98926.

J. M. Stock, Seismological Laboratory, California Institute of Technology, 252-21, Pasadena, CA 91125. (e-mail:

jstock@seismo.gps.caltech.edu)

(Received December 27, 1993;

revised July 7, 1994; accepted July 12, 1994.) 